Journal of Science Education Research

Journal homepage: www.journal.uny.ac.id/jser

\title{
JSER
}

\section{Developing the Character-Based Students Worksheet of Science with Inquiry Model for Students of Grade IX}

\author{
Melkyanus Kaleka ${ }^{1}$, Yasinta E. Ika ${ }^{2}$ \\ ${ }^{1,2,3}$ Study Program of Physics Education, Faculty of Teacher Training and Education, University of Flores \\ Corresponding Author. Email: eka.umbu@yahoo.co.id
}

Keywords:
Student
Worksheet of
Science,
Character
Education,
Inquiry Model

Keywords:

Student

Worksheet of

Science,

Character

Inquiry Model

\begin{abstract}
Student Worksheet (LKS) is a learning media as a means to train the students to think, act and having an attitude like a young scientist. The purpose of the particular study was to produce a character-based LKS of Science with inquiry model and analyzing the development of the LKS on students' achievement and character. This research was a developmental research. The research sample was the students of class IXa as the experimental class and students of class IXd as the control class. The sampling technique used purposive sampling. Research procedures were; introduction, design, and development. Data collection techniques were the questionnaire, test, and documentation. Data analysis techniques used the percentage, t-test, and gain test. The results of the analysis concluded that the character-based Students Worksheets with inquiry model was very feasible to be used as a learning guide for a science subject. There is a significant difference in learning achievement between students in the experimental class and students in the control class.
\end{abstract}

C2018 JSER. Yogyakarta State University

\section{INTRODUCTION}

Student Worksheet (LKS) is a learning media and always used by teachers in science learning activities. LKS must become a source of learning for students which can provide experience and skills in the learning process, as well as to build an attitude or character in students.

Based on the observations, a fact found in several junior high schools in Ende regency; the Student Worksheet of science contains tasks and experimental activities that end with a discussion on questions. Most of the student worksheets already contain a series of experimental activities, so the students only follow the guidance on LKS. Students do not train to find the problems, propose hypotheses, and determine the experimental steps for problem-solving. The student worksheet has not function yet to build the attitude or character of students in the learning process. LKS or good learning media, as stated by Gerlach and Ely in Arsyad (2007: p.3), that the real media is human, material, or event that make the students acquire the knowledge, skills, and attitudes.

There needs to develop a character-based student worksheet to train the students to act and think like a scientist in solving a problem. The opinion stated by Salis (2016: p.7), the student is guided to make a tentative conclusion, which makes the learning activities similar to research activities that are usually performed by experts. In learning a concept of physics, the student is needed to learn following the stages of the investigation as a whole, and then the students' understanding is more complete and mere memorizing the formulas and concepts of physics.

LKS might become an effective learning media by selecting the appropriate learning model. The inquiry model is a student-centered learning model. The core of inquiry learning involves the students actively in taking the steps in the inquiry learning. The steps or inquiry process are; problem identification, variables identification, proposing the hypotheses, planning the investigations, carrying out 
the investigations, data collection, data display, interpret the data, and drawing conclusions. These steps are characteristic of the scientific approach. Johnstone and Shuaili (2001: p. 45) described the characteristics of the LKS inquiry, are: (1) the results of observations have not been determined, so the students can determine by themselves, (2) an inductive approach is observing the complex examples in order the students can find the concepts of learning, and (3) the experimental procedures are developed by students.

According to Permendikbud (Minister of Education and Culture) No. 64 of 2013 on the standard content of primary and secondary education, an objectives of science subjects at junior high school is; the students are expected to be able to develop the attitude of curiosity, honest, responsible, logical, critical, analytical, and creative. Therefore, it needs to develop a learning media to build the character in students. Character-based learning media are expected to contribute indirectly to the building of quality Human Resources (HR). The quality of human resource is the future generation of the nation with character, moral quality and intellectual intelligence. Today, many humans are intelligent, but the morals are poor. Therefore, the future generations must be taught a good character, in order they become the golden generation to build Indonesia (Ministry of National Education, 2011: p. 2-7).

The purpose of this developmental research was to develop student worksheets that able to build the students' character by applying inquiry learning models on the material of dynamic electricity. The character values are curiosity, creative, honest, confident, disciplined and responsible.
The research was research and development. A big group trial test used Quasi Experimental Design in the form of Nonequivalent Control Group Design. The design of this study used experimental class and control class which was not chosen randomly. This study divided into three stages; preliminary study, design, and development. The steps of research and development are presented in Figure 1.

The factors of the particular study were the feasibility of Student Worksheets, the differences in students' achievement, students' understanding, and students' character. Data collections were a questionnaire, test, and documentation. The data were qualitative and quantitative. Data analysis techniques used percentage, t-test, and gain test. All the analysis results are continued to interpret on a qualitative scale.

1. Analysis of the Feasibility of student worksheet The level of LKS feasibility is calculated through the percentage. According to Purwanto (2012), the equation below might be used to calculate the percentage of a score;

$N P=\frac{R}{S M} \times 100 \%$

Where:

$\mathrm{NP} \quad=$ The score of percentage

$\mathrm{R}=$ The total of obtained score

$\mathrm{SM}=$ The ideal maximum score

The level criteria of LKS feasibility:

$21 \%<\mathrm{p} \leq 40 \%=$ poor of feasible

$41 \% \leq \mathrm{p} \leq 60 \%=$ medium of feasible

$61 \% \leq \mathrm{p} \leq 80 \%=$ feasible

$81 \% \leq \mathrm{p} \leq 100 \%=$ very feasible

\section{METHOD}

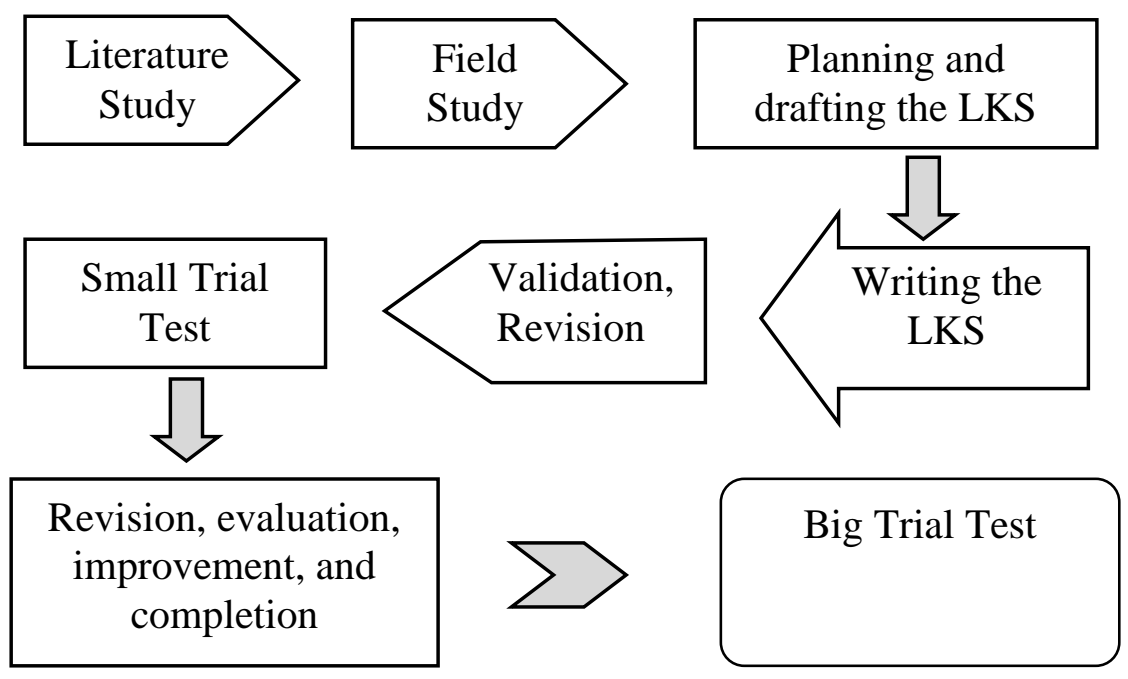

Figure 1. The procedures of Research and Development 
Melkyanus Kaleka, Yasinta E. Ika, / JSER 2018, 2(2), 68

2. Analysis of Students' Achievement

The t-test was used to know the differences in the students' score after treated using student worksheet. According to Riduan (2012: p.165), ttest is formulated in the following equation;

$$
t=\frac{\bar{x}_{1}-\bar{x}_{2}}{\sqrt{\frac{S_{1}}{n_{1}}+\frac{S_{2}}{n_{2}}-2 r\left(\frac{s_{1}}{\sqrt{n_{1}}}\right)+\left(\frac{s_{2}}{\sqrt{n_{2}}}\right)}}
$$

Where:

$$
\begin{array}{ll}
\mathrm{r} & =\text { correlation score } \mathrm{X}_{1} \text { and } \mathrm{X}_{2} \\
\mathrm{n} & =\text { total sample } \\
\bar{x}_{1} & =\text { average score of the experiment class } \\
\bar{x}_{2} & =\text { average score of the control class } \\
s_{1} & =\text { standard deviation of the experiment class } \\
s_{2} & =\text { standard deviation of the control class } \\
\mathrm{S}_{1} & =\text { Variance in the experiment class } \\
\mathrm{S}_{2} & =\text { Variance in the control class }
\end{array}
$$

The gain test was used to find out the improvement of students' learning outcome. According to Hake (in Meltzer: 2002, p.70), the gain test is formulated in the following equation:

$$
\langle g\rangle=\frac{\left\langle S_{\text {post }}\right\rangle-\left\langle S_{\text {pre }}\right\rangle}{100 \%-\left\langle S_{\text {pre }}\right\rangle}
$$

Where:

$$
\begin{aligned}
& \langle\mathrm{g}\rangle \quad=\text { factor of gain } \\
& \langle\text { Spre }\rangle \quad=\text { average score of initial test }(\%) \\
& \langle\text { Spost }\rangle \quad=\text { average score of final test }(\%)
\end{aligned}
$$

Factor Criteria of gain $\langle\mathrm{g}\rangle$ :

$$
\mathrm{g} \geq 0,7 \quad=\text { High }
$$

$$
\begin{array}{ll}
0,3 \leq \mathrm{g}<0,7 & =\text { Medium } \\
\mathrm{g}<0,3 & =\text { Poor }
\end{array}
$$

\section{RESULT}

Table 1 shows the assessment of character Student Worksheets of natural with inquiry model, as a product of development from the respondent (teachers), which the content feasibility obtained an average score of 3.85 with criteria of "very feasible", the language aspect obtained an average score of 3.98 with criteria of "very feasible", and the display aspect obtained an average score of 4.0 with criteria of "very feasible". In sum, the Student Worksheet has claimed as feasible to be used as learning media. In line with a research conducted by Budiman et al (2014: p. 7), that character-based student worksheets of science were effective to be

\begin{tabular}{|c|c|c|c|c|}
\hline \multirow{2}{*}{ NO } & \multirow{2}{*}{ Respondent } & \multicolumn{3}{|c|}{ Score on each component } \\
\hline & & Content & Language & Display \\
\hline 1 & R01 & 3,80 & 4,00 & 4,00 \\
\hline 2 & $\mathrm{R} 02$ & 3,90 & 3,93 & 4,00 \\
\hline 3 & R03 & 3,80 & 4,00 & 4,00 \\
\hline 4 & R04 & 3,90 & 4,00 & 4,00 \\
\hline \multicolumn{2}{|c|}{ Average Score } & 3,85 & 3,98 & 4,00 \\
\hline \multicolumn{2}{|c|}{ Presentation } & 96,25 & 99,55 & 100,00 \\
\hline \multicolumn{2}{|c|}{ Criteria } & $\begin{array}{c}\text { Very } \\
\text { Feasible }\end{array}$ & $\begin{array}{c}\text { Very } \\
\text { Feasible }\end{array}$ & $\begin{array}{c}\text { Very } \\
\text { Feasible }\end{array}$ \\
\hline \multicolumn{2}{|c|}{$\begin{array}{l}\text { Average of } \\
\text { presentation }\end{array}$} & \multicolumn{3}{|c|}{98,60} \\
\hline \multicolumn{2}{|c|}{ Criteria } & \multicolumn{3}{|c|}{ Very Feasible } \\
\hline
\end{tabular}
used as teaching materials in the learning process because more than $60 \%$ of students had mastery the learning objectives

Cognitive learning achievement is obtained through written tests. Written tests are carried out before and after learning using the character-based Student Worksheets of science students with inquiry model. The cognitive learning achievement is analyzed using the gain test and t-test. The gain test aims at determining the significance of improving the learning achievement. The t-test aims to find out the differences the average of learning achievement before and after learning using the Student Worksheet

Table 1. The Result of feasibility test on the student worksheets 
Table 2. The learning achievement of students' cognitive

\begin{tabular}{cccc}
\hline Class & $\begin{array}{c}\text { Average of } \\
\text { Pre-test }\end{array}$ & $\begin{array}{c}\text { Average of } \\
\text { Post-test }\end{array}$ & $\begin{array}{c}\text { Enhancement } \\
\text { Criteria }\end{array}$ \\
\hline Experiment & 48,03 & 66,52 & Medium \\
\hline Control & 43,24 & 43,68 & Medium \\
\hline
\end{tabular}

Table 3. The Analysis Result of Students' Character

\begin{tabular}{cccc}
\hline $\begin{array}{c}\text { Students' } \\
\text { character }\end{array}$ & $\begin{array}{c}\text { Before the } \\
\text { treatment } \\
(\%)\end{array}$ & $\begin{array}{c}\text { After the } \\
\text { treatment } \\
(\%)\end{array}$ & Gain \\
\hline Curiosity & 82,26 & 83,91 & Poor \\
Creative & 63,39 & 66,09 & Poor \\
Honest & 72,81 & 74,52 & Poor \\
Confident & 83,23 & 84,06 & Poor \\
Disciplined & 88,44 & 90,48 & Poor \\
Responsible & 81,25 & 81,45 & Poor \\
\hline Average & 78,56 & 80,09 & Poor \\
\hline
\end{tabular}

The analysis results showed that the students' conceptual understanding increases after learning. The gain factor was 0.36 in the experimental class and 0.01 in the control class. Then, it might be stated that the improvement of concept understanding on science material of the electrical circuit is in the medium category in the experimental class and poor category in the control class. Based on the analysis, concluded that the students' conceptual understanding of experimental class is higher than control class students.

The analysis results of t-test showed that there are significant differences in the learning achievement between experiment class and control class. From the differences in the learning achievement, the Character-based Student Worksheets with inquiry model are effective to be used as a means in science learning for students in grade IX. The differences are caused by the learning, which is through a scientific investigation. In the learning, the students have experienced a scientific work process, including; students provide temporary answers to an issue that will be investigated, students can design the investigations, retrieve the data, data processing, and drawing conclusions

The characters in the particular study are curiosity, creative, honest, confident, disciplined, and responsible. Data on character development obtained through questionnaires. The values of student character development were analyzed using gain test. The analysis results of student character are presented in table 3.

The data on analysis results of character showed that there is an increase (despite a small increase) in the character of curiosity before and after the learning using the Character-based Student Worksheets of science with the inquiry model. Also, there is an increase (despite in the category of development) in the character of honest before and after the learning using the Character-based Student Worksheets of science with the inquiry model. And, the character of disciplined has in the category of entrenched or habitual before and after the learning. The entrenched or habitual means the students have very good of a disciplined character.

\section{CONCLUSION}

Based on the discussion, concluded that: (1) the character-based Student Worksheets of science with inquiry models are very feasible to be used as a means in learning for students in grade IX of junior high school; (2) there is a significant difference between the students' achievement using the character-based Student Worksheets of science with inquiry models and the students' achievement using conventional models of Student Worksheets; (3) The use of the character-based Student Worksheets of science with inquiry models can develop the students' character, which is on the criteria of entrenched or habitual.

\section{REFERENCES}

Arsyad, Azhar. (2007). Media Pembelajaran. Jakarta: PT Raja Grafindo.

Budiman, Herpratiwi, Undang Rosidin. (2014). Pengembangan Modul Pembelajaran IPA Berbasis Karakter Materi Kalor SMP Kelas VII di Bandar Lampung. Jurnal Sains dan Pendidikan. 1(1) 1-8

Fitriyati, E. S. Kurniawan, \& N. Ngazizah. (2013). Pengembangan LKS Fisika SMA Kelas X Semester II dengan Website Online Berbasis 
Melkyanus Kaleka, Yasinta E. Ika, / JSER 2018, 2(2), 70

Contextual Teaching Learning. Jurnal Radiasi, 3(1): 7-11

Johnstone, A. H., dan Shuaili, A. (2001). Learning in Laboratory, Some Thought form The Literature. The Royal Society of Chemistry.

Kemendiknas, Badan Penelitian dan Pengembangan 2011. Pedoman Pelaksanaan Pendidikan Karakter. Jakarta: Kementerian Pendidikan Nasional.

Meltzer, D.E. (2002). "The Relationsip Between Mathematics Prepartion and Conceptual Learning gains in Physics: Posisible "Hidden Variable" in Diagnostic Pretest
Scores", American Journal of Physics. $70(7)$.

Permendikbud No. 64 Tahun 2013 tentang Standar Isi

Purwanto,N. (2012). Prinsip-Prinsip dan Teknik Evaluasi Pengajaran. Bandung: Remaja Rosdakarya.

Riduwan, M.B.A. (2012). Belajar Mudah Penelitian untuk Guru-Karyawan dan Peneliti Pemula. Bandung: Alfabeta

Salis Ahda. (2016). Model Pembelajaran Inquiry Link Maps (PILM). Malang: Penerbit Universitas Negeri Malang (UM PRESS). 